\section{Cureus}

\title{
Gastrointestinal Seed Bezoars: A Systematic Review of Case Reports and Case Series
}

Dimitrios K. Manatakis ${ }^{1}$, Vasileios Acheimastos ${ }^{1}$, Maria Ioanna Antonopoulou ${ }^{1}$, Dimitrios Balalis $^{2}$, Dimitris P. Korkolis ${ }^{2}$

1. Surgery, Athens Naval and Veterans Hospital, Athens, GRC 2. Surgery, Saint Savvas Cancer Hospital, Athens, GRC

Corresponding author: Dimitrios K. Manatakis, dmanatak@yahoo.gr

\section{Abstract}

Seed bezoars are a distinct subcategory of phytobezoars, caused by indigestible vegetable or fruit seeds. The aim of our study was to present a comprehensive review on seed bezoars, focusing on epidemiology, symptomatology, diagnosis and treatment options.

A systematic review of the English literature (1980-2018) was conducted, using PubMed, Embase and Google Scholar databases. Fifty-two studies fulfilled the inclusion criteria, with a total of 153 patients, the majority of whom (72\%) came from countries around the Eastern Mediterranean and the Middle East.

Patients complained primarily about constipation (63\%), abdominal/rectal pain (19\%) or intestinal obstruction (17\%). Most seed bezoars were found in the rectum (78\%) and the terminal ileum (16\%). Risk factors were recognised in $12 \%$ of cases. Manual disimpaction under general anaesthesia was the procedure of choice in $69 \%$, while surgery was required in $22 \%$ of cases.

Seed bezoars appear to represent a different pathophysiological process compared to fibre bezoars. Seeds usually pass through the pylorus and ileocaecal valve, due to their small size, and accumulate gradually in the colon. Seed bezoars are usually found in the rectum of patients without predisposing factors, causing constipation and pain. History and digital rectal examination are the mainstay of diagnosis, with manual extraction under general anaesthesia being the procedure of choice.

Categories: Emergency Medicine, Gastroenterology, General Surgery

Keywords: bezoar, phytobezoar

\section{Introduction And Background}

Bezoars are retained aggregates of indigestible material that accumulate and conglomerate in the gastrointestinal tract. They can occur anywhere from the oesophagus to the rectum, however, they are most commonly found in the stomach. Recognised risk factors are prior gastric surgery, neuropsychiatric disease, endocrinopathies impairing gastrointestinal motility and poor mastication $[1,2]$.

Based on their component, they are classified into four main types: phytobezoar (fruit and vegetable fibres), trichobezoar (hair), lactobezoar (undigested milk concretions) and pharmacobezoar (medications) [1, 2]. Seed bezoars are a distinct subtype of phytobezoars, caused by undigested vegetable seeds or fruit pits. In contrast to other bezoar categories, the 
majority is found in the rectum of patients with no predisposing factors, a fact suggesting a different pathophysiological process [3, 4].

We hereby present a systematic, up-to-date review of case reports and case series of gastrointestinal seed bezoars, with emphasis on epidemiology, diagnosis and treatment options.

\section{Review}

\section{Methods}

We performed a systematic review of the literature, following the Meta-Analysis of Observational Studies in Epidemiology (MOOSE) guidelines, in order to identify all studies of patients with gastrointestinal seed bezoars [5]. Literature searches were conducted in PubMed/MEDLINE, EMBASE and Google Scholar bibliographic databases, spanning years 1980 to 2018. The keywords "bezoar", "phytobezoar", "seed”, "grain” and "pit” were used in all possible combinations. Moreover, the reference lists of all eligible studies were assessed for additional articles.

All study designs (case series and case reports) were eligible for inclusion in the final analysis. Patient age was not an exclusion criterion, and both adult and paediatric cases were included in the review. Articles without full text availability were excluded.

Titles and abstracts of all articles from the initial search were independently screened by two authors, to determine those articles for full text review. Any discrepancies concerning the evaluation of the studies were arbitrated by all authors. A flow chart of study selection is shown in Figure 1.

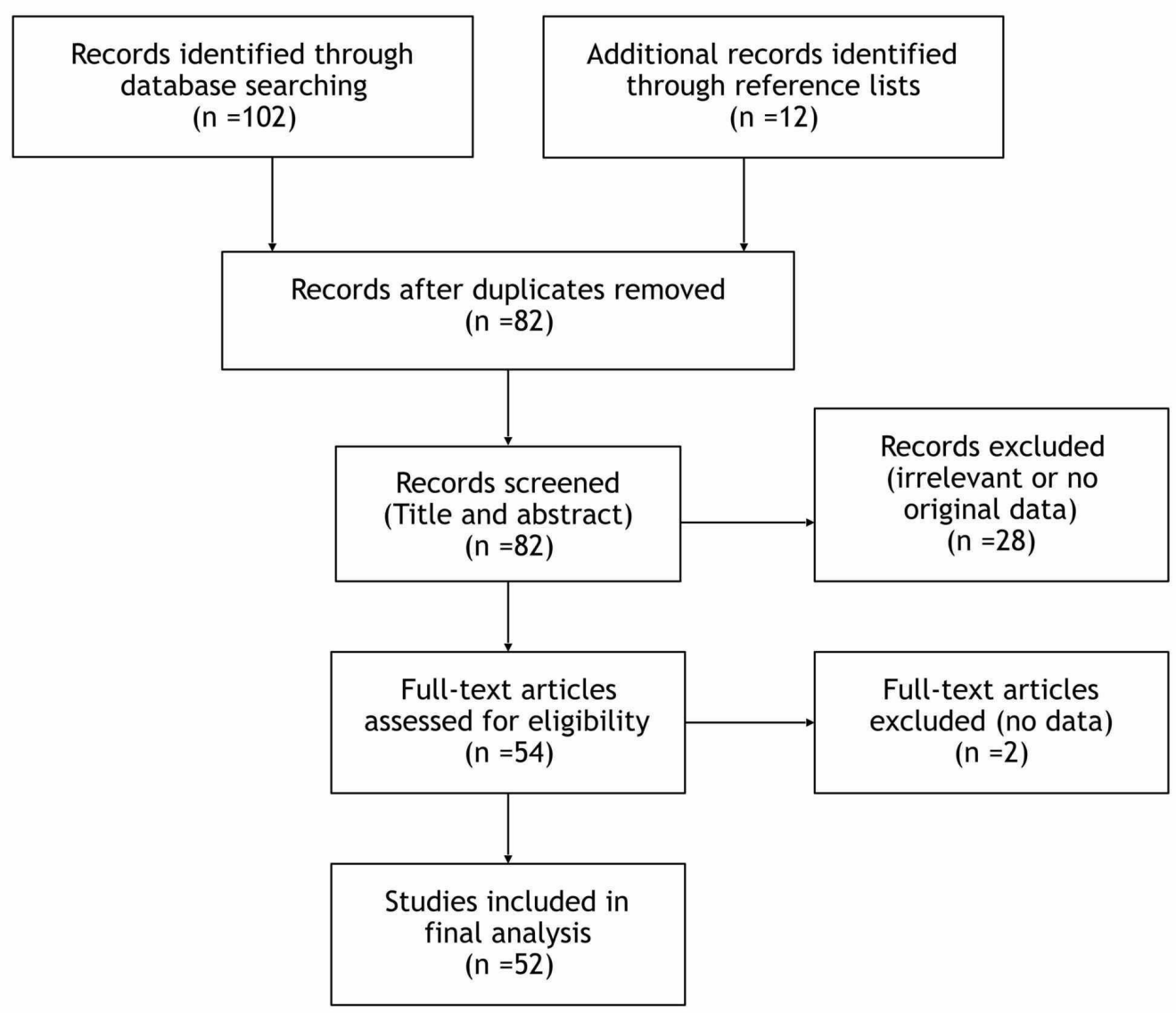




\section{Cureus}

\section{FIGURE 1: Flowchart of literature search}

For each eligible study, data were extracted about demographic (number of patients, age, sex, and country of origin) and clinical characteristics (seed type, predisposing factors, bezoar location, clinical presentation, diagnostic and therapeutic management).

Statistical analysis was performed on SPSS, version 20.0 (IBM Corp, Armonk, NY). All data were tabulated and outcomes were cumulatively analysed. Continuous variables were expressed as mean \pm standard deviation, while categorical variables were expressed as frequencies or percentages. Additionally, adult and paediatric subgroups were compared, using Student's ttest for continuous variables and chi-square or Fisher's exact test for categorical variables. Statistical significance was set to $\mathrm{p}<0.05$.

\section{Results}

Fifty-two studies were included in the final analysis (two retrospective case series and 50 case reports), with a total of 153 patients (Appendix). Demographic characteristics of patients are presented in Table 1.

$\mathbf{N}$

Gender

Male

Female

Age range

Paediatric cases

Adult cases

Country of origin

Eastern Mediterranean basin - Middle East

Western Europe - America

Asia-Oceania

\section{3}

90

63

$2-80$ years

$2-16$ years (median 10 years)

$18-80$ years (median 44 years)

$110(71.9 \%)$

$29(19.0 \%)$

$14(9.1 \%)$

\section{TABLE 1: Demographic characteristics of seed bezoar cases}

The vast majority of cases $(110 / 153,71.9 \%)$ came from countries of the eastern Mediterranean basin and the Middle East, whereas 29 patients (19.0\%) came from Western countries and 14 (9.1\%) from Asia.

As far as the type of seed is concerned, most patients (55/153, 36.0\%) consumed watermelon seeds (45 children, 10 adults), followed by sunflower seeds (30/153, 19.6\%, 18 children, 12 adults) and prickly pears (28/153, 18.3\%, six children, 22 adults). Other cases involved wild 
banana seeds (11/153, 7.2\%), pumpkin seeds (5/153, 3.3\%), pomegranate seeds (4/153, $2.6 \%)$, date seeds (2/153, 1.3\%), tangerine pits (2/153, $1.3 \%)$, olive pits $(2 / 153,1.3 \%)$, lupin seeds (2/153, 1.3\%), pop corn kernels (2/153, 1.3\%), freekeh grains, sesame seeds, Baccaurea macrocarpa seeds, jaboticaba seeds, peanuts, lentil seeds, cherry pits, box myrtle seeds, mango seeds and granadilla seeds (one case each, $0.65 \%$ ).

The majority of patients presented at the emergency department complained of constipation (96/153, 62.7\%, 57 children, 39 adults). Twenty-nine patients (19.0\%, 17 children, 12 adults) reported atypical abdominal or rectal pain accompanied by tenesmus or blood-tinged stools. The diagnostic workup revealed intestinal obstruction in 26 cases (17.0\%, nine children, 17 adults). One elderly patient was diagnosed with acute abdomen due to rectal perforation, while in one case the seed bezoar was an incidental intraoperative finding. Risk factors for bezoar formation were recognised in 18 cases (11.7\%, one child, 17 adults) and included gastrointestinal strictures (10/153, 6.5\%), diabetes (4/153, 2.6\%) and neuropsychiatric disease (4/153, 2.6\%).

A thorough history and digital rectal examination at the emergency room usually hinted at the diagnosis. Endoscopy was employed in 20 patients (13.1\%) and radiology (X-rays or abdominal CT scans) in 20 patients (13.1\%). Rectal bezoars were found in 119 cases (77.8\%, 70 children, 49 adults), followed by bezoars in the terminal ileum in 25 cases (16.3\%, 11 children, 14 adults). In three cases (1.9\%) bezoars were located in the sigmoid colon, in two cases each (1.3\%) in the stomach and jejunum, whereas in one case each (0.66\%), in the duodenum and caecum. Treatment options included manual disimpaction (106/153, 69.3\%, 65 children, 41 adults), surgery (33/153, 21.5\%, 12 children, 21 adults), endoscopy (5/153, 3.3\%, five adults) or conservative measures $(9 / 153,5.9 \%$, six children, three adults) (Table 2$)$. 


\section{Cureus}

Clinical presentation

Constipation

Abdominal/rectal pain

Intestinal obstruction

26

Rectal perforation

Asymptomatic finding

Diagnostic workup

Endoscopy

Radiology (X-rays, CT scans)

Treatment

Manual disimpaction

Surgery

Endoscopy

9

5.9

\section{TABLE 2: Clinical characteristics of seed bezoar cases}

Comparison of paediatric and adult populations (Table 3) showed that gender did not differ significantly between the two groups $(p=0.09)$, whereas consumption of watermelon seeds was more popular among children and of prickly pears among adults $(\mathrm{p}<0.0001)$. 


\section{Cureus}

\begin{tabular}{|c|c|c|c|c|c|}
\hline & Children & $\%$ & Adults & $\%$ & $p$-value \\
\hline $\mathrm{N}$ & 83 & & 70 & & \\
\hline Age (years) & 2-16 (median 10) & & 18-80 (median 44) & & \\
\hline \multicolumn{6}{|l|}{ Gender } \\
\hline Male & 54 & 65.1 & 36 & 51.4 & \\
\hline Female & 29 & 34.9 & 34 & 48.6 & 0.09 \\
\hline \multicolumn{6}{|l|}{ Seed type } \\
\hline Watermelon & 45 & 54.2 & 10 & 14.3 & \\
\hline Sunflower & 18 & 21.7 & 12 & 17.1 & \\
\hline Prickly pear & 6 & 7.2 & 22 & 31.4 & $<0.0001$ \\
\hline \multicolumn{6}{|l|}{ Localisation } \\
\hline Rectum & 70 & 84.3 & 49 & 70 & \\
\hline Terminal ileum & 11 & 13.3 & 14 & 20 & 0.17 \\
\hline \multicolumn{6}{|l|}{ Symptoms } \\
\hline Constipation & 57 & 68.7 & 39 & 55.7 & \\
\hline Abdominal/rectal pain & 16 & 19.3 & 12 & 17.1 & \\
\hline Intestinal obstruction & 9 & 10.8 & 17 & 24.3 & 0.07 \\
\hline \multicolumn{6}{|l|}{ Treatment } \\
\hline Manual disimpaction & 65 & 78.3 & 41 & 58.6 & \\
\hline Surgery & 12 & 14.5 & 21 & 30 & \\
\hline Conservative/endoscopy & 6 & 7.2 & 8 & 11.4 & 0.03 \\
\hline Risk factors & 1 & 1.2 & 17 & 24.3 & $<0.0001$ \\
\hline
\end{tabular}

TABLE 3: Comparison of paediatric versus adult cases

In both groups, the rectum was the most common location of the seed bezoar and constipation was the prevailing symptom. Intestinal obstruction was more frequent in adults than in children $(24.3 \%$ vs $10.8 \%)$, however it marginally did not reach statistical significance $(\mathrm{p}=$ 0.07). Manual disimpaction was the procedure of choice in the majority of both children (78.3\%) and adults (58.6\%). Surgical exploration was required more commonly in adults (30\% vs 14.5\%, $\mathrm{p}=0.03$ ). Finally, predisposing factors were more frequently reported in adult than in paediatric cases $(24.3 \%$ vs $1.2 \%, \mathrm{p}<0.0001)$.

\section{Discussion}


The word "bezoar" derives its etymology from the Persian word "padzahr" or the Arabic "badizahr", which both mean "antidote" [1]. Indeed, bezoars had been ascribed mystical powers and were popular through the Middle Ages as remedies against a variety of poisons [1, 6]. It was not until the 19th century that they were recognised as potentially serious medical conditions, being the cause of 3-7\% of small intestinal obstructions [7, 8].

Seed bezoars are a distinct subgroup of phytobezoars, caused by the accumulation of indigestible vegetable or fruit seeds in the intestinal lumen. Grains and seeds usually pass through the pylorus and the ileocaecal valve, due to their small size, and accumulate gradually in the colon $[3,4,9]$. Reaching the rectum, the faecal mass is further dehydrated and forms a hard bezoar, commonly presenting as faecal impaction. This pathophysiological process of seed bezoars appears to be different from fibre bezoars, which are usually found in the stomach. Fibres contained in fruits and vegetables (cellulose, lignin, tannins) polymerise and agglutinate in the acidic environment of the stomach, and form a glue-like coagulum which affixes to other material and only rarely overcomes the pyloric sphincter $[8,10]$.

This hypothesis of different pathophysiology is further supported by the fact that seed bezoars seem to arise in patients without predisposing factors [3, 4]. In our review, previous gastric surgery, neuropsychiatric disease and endocrinopathies (diabetes, hypothyroidism) were recognised only in $12 \%$ of cases. On the contrary, retrospective series of gastric and intestinal fibre bezoar cases reported rates of risk factors exceeding $85 \%$ [7, 8, 11]. As expected, we observed these predisposing conditions significantly more frequently in adult patients compared to children $(24.3 \%$ vs $1.2 \%, \mathrm{p}<0.0001)$.

Another interesting observation is the geographical distribution of cases, which may reflect the dietary habits across the Mediterranean basin and the Middle East, a diet still including fresh fruits and vegetables, as opposed to the "typical" western diet, based on processed carbohydrates and saturated fats [7]. Watermelons and prickly pears are common delicacies consumed during summer months, while dried sunflower and pumpkin seeds are a favourite snack among all ages and seasons.

As far as the clinical presentation is concerned, the pooled analysis found that seed bezoars occurred most frequently in the rectum, in both children and adults ( $84 \%$ and $70 \%$, respectively). The primary complain was therefore constipation (69\% of children, $56 \%$ of adults), followed by non-specific abdominal or rectal pain ( $19 \%$ of children, $17 \%$ of adults). Intestinal obstruction was relatively rare (17\%) and mainly affected those patients with seed bezoars in the terminal ileum. While bowel perforation is the most feared complication, peritonitis was reported only in one case. On the contrary, fibre bezoars in the stomach may run asymptomatic for years or present with vague, non-specific symptoms including epigastric discomfort, abdominal bloating, nausea and vomiting, early satiety, post-prandial fullness, halitosis and weight loss [1].

Diagnosis of seed bezoars should be fairly straightforward, suggested by a careful history. Digital per rectum examination is the sine-qua-non of the diagnostic workup, aided by rectoscopy in selected cases. A full colonoscopy may be advisable in adult patients, to exclude malignant pathology, following bezoar extraction.

On the other hand, seed bezoars in the small intestine and colon are trickier to diagnose and require further investigations. Plain abdominal radiographs may show a solid stool mass, but generally they are within normal limits. Computerised tomography scans are considered the gold standard of diagnosis, offering information about the type, location and degree of obstruction, as well as potential bowel wall ischemia [12, 13]. Of the 20 patients who required supplementary imaging studies, $70 \%$ had bezoars proximal to the rectum. 


\section{Cureus}

In children with ambiguous right lower quadrant or hypogastric pain, negative imaging studies and suspicion of acute appendicitis, a digital rectal examination should not be omitted. Of 83 children diagnosed with seed bezoars, five had been admitted in hospital with an initial working diagnosis of appendicitis and in three of them a rectal bezoar was revealed, thus eliminating the need for surgery.

Manual evacuation under general anaesthesia is the procedure of choice for rectal seed bezoars, to minimise patient discomfort, while surgery is practically inevitable for small bowel seed bezoars presenting as intestinal obstruction [7]. Indeed, among the 33 cases of operative management in this review, 31 cases concerned seed bezoars of the stomach, duodenum, small and large bowel, proximal to the rectum. Depending on the intraoperative findings, the surgeon may choose between enterotomy and removal of the obstructing bezoar, fragmentation and milking of the bezoar through the ileocaecal valve, and segmental enterectomy.

Only 2/119 (1.7\%) rectal seed bezoars required surgical intervention, while only 3/34 (8.8\%) gastrointestinal seed bezoars were managed non-operatively with success. Furthermore, whereas manual disimpaction was the most commonly performed therapeutic procedure in both children and adults ( $78 \%$ and $59 \%$, respectively), surgery was more frequently needed in adult patients ( $30 \%$ vs $14.5 \%, \mathrm{p}=0.03$ ).

Although conservative treatment (endoscopy or chemical dissolution) works well for fibre bezoars, it does not appear to be efficient in patients with seed bezoars [7, 14, 15]. Our review showed that only $6 \%$ of seed bezoars were amenable to conservative measures (fleet enemas, stool softeners). Moreover, endoscopy alone usually failed to extract the bezoar, since the endoscope could not pass beyond the seed mass without risking perforation of the rectum, being successful only in $3 \%$ of cases.

\section{Conclusions}

In conclusion, seed bezoars should be considered as a distinct subgroup of phytobezoars, with different pathophysiology compared to bezoars caused by fibre accumulation. They are usually found in the rectum of children and adults without predisposing factors, causing constipation and pain. History and digital rectal examination are the cornerstones of diagnosis. In most patients rectal seed bezoars can be manually extracted under general anaesthesia, whereas intestinal seed bezoars are usually found in the terminal ileum causing intestinal obstruction and therefore mandate operative intervention.

\section{Appendices}

\begin{tabular}{|c|c|c|c|c|c|c|}
\hline $\begin{array}{l}\text { 1st } \\
\text { Author }\end{array}$ & Year & Country & Journal & $\begin{array}{l}\text { Article } \\
\text { Data }\end{array}$ & Title & $\mathbf{N}$ \\
\hline Melchreit & 1984 & USA & N Engl J Med & $\begin{array}{l}310: 1748- \\
9\end{array}$ & 'Colonic crunch' sign in sunflower-seed bezoar & 1 \\
\hline Cloonan & 1988 & USA & $\begin{array}{l}\text { Ann Emerg } \\
\text { Med }\end{array}$ & $17: 873-4$ & Rectal bezoar from sunflower seeds & 1 \\
\hline Roberge & 1988 & USA & $\begin{array}{l}\text { Ann Emerg } \\
\text { Med }\end{array}$ & $17: 131-3$ & Popcorn Primary Colonic Phytobezoar & 1 \\
\hline Dent & 1989 & USA & Am J Dis Child & 143:643-4 & Sunflower seed bezoar presenting as diarrhea & 1 \\
\hline Meeroff & 1989 & USA & $A m \mathrm{~J}$ & $84: 650-2$ & Gastric lupinoma: a new variety of phytobezoar & 1 \\
\hline
\end{tabular}




\section{Cureus}

\begin{tabular}{|c|c|c|c|c|c|c|}
\hline & & & Gastroenterol & & & \\
\hline Shah & 1990 & USA & $\begin{array}{l}\text { Pediatr Emerg } \\
\text { Care }\end{array}$ & 6:127-8 & $\begin{array}{l}\text { Polyethylene glycol-electrolyte solution for rectal sunflower } \\
\text { seed bezoar }\end{array}$ & 1 \\
\hline Philips & 1991 & USA & $\begin{array}{l}\text { Ann Emerg } \\
\text { Med }\end{array}$ & $20: 171-2$ & Sunflower Seed Syndrome: A prickly proctological problem & 1 \\
\hline Tsin & 1994 & Israel & Harefuah & $127: 227-8$ & Intestinal obstruction due to lupin phytobezoar in a child & 1 \\
\hline Purcell & 1995 & USA & South Med J & $88: 87-8$ & Sunflower seed bezoar leading to fecal impaction & 2 \\
\hline Efrati & 1997 & Israel & $\begin{array}{l}\text { J Pediatr } \\
\text { Gastroenterol } \\
\text { Nutr }\end{array}$ & $25: 214-6$ & $\begin{array}{l}\text { Phytobezoar-induced ileal and colonic obstruction in } \\
\text { childhood }\end{array}$ & 3 \\
\hline Tsou & 1997 & USA & Pediatrics & $99: 896-7$ & Colonic sunflower seed bezoar & 2 \\
\hline Burstein & 2000 & Israel & $\begin{array}{l}\text { Israel Med } \\
\text { Assoc J }\end{array}$ & 2:129-31 & $\begin{array}{l}\text { Small Bowel Obstruction and Covered Perforation in } \\
\text { Childhood Caused by Bizarre Bezoars and Foreign Bodies }\end{array}$ & 1 \\
\hline Moons & 2000 & Netherlands & $\begin{array}{l}\text { Ned Tijdschr } \\
\text { Geneeskd }\end{array}$ & $\begin{array}{l}144: 1878- \\
8\end{array}$ & Severe obstipation due to eating unshelled sunflower seeds & 2 \\
\hline Lowry & 2001 & USA & $\begin{array}{l}\text { Gastrointest } \\
\text { Endosc }\end{array}$ & $53: 388-9$ & Sunflower seed rectal bezoar in an adult & 1 \\
\hline Pitiakoudis & 2003 & Greece & $\begin{array}{l}\text { Acta Chir } \\
\text { lugosl }\end{array}$ & $50: 131-3$ & $\begin{array}{l}\text { Phytobezoars as a cause of small bowel obstruction } \\
\text { associated with a carcinoid tumor of the ileocecal area }\end{array}$ & 1 \\
\hline Sawnani & 2003 & USA & $\begin{array}{l}\text { J La State Med } \\
\text { Soc }\end{array}$ & 155:163-4 & Proctological crunch: sunflower-seed bezoar & 1 \\
\hline Steinberg & 2003 & Israel & $\begin{array}{l}\text { Int J Colorectal } \\
\text { Dis }\end{array}$ & 18:365-7 & $\begin{array}{l}\text { Prickly pear fruit bezoar presenting as rectal perforation in an } \\
\text { elderly patient }\end{array}$ & 1 \\
\hline Schoffl & 2004 & Laos & Asian J Surg & $27: 348-51$ & $\begin{array}{l}\text { Intestinal obstruction due to phytobezoars of banana seeds: } \\
\text { A case report }\end{array}$ & 4 \\
\hline Alexander & 2005 & India & $\begin{array}{l}\text { Indian J } \\
\text { Gastroenterol }\end{array}$ & $24: 273-4$ & $\begin{array}{l}\text { Cherry pip bezoars causing acute small intestinal obstruction } \\
\text { presenting as diabetic ketoacidosis }\end{array}$ & 1 \\
\hline Bakr & 2006 & UAE & Acta Paediatr & $95: 886-7$ & Rectal sunflower seed bezoar & 1 \\
\hline Eitan & 2006 & Israel & $\begin{array}{l}\text { Dis Colon } \\
\text { Rectum }\end{array}$ & $\begin{array}{l}49: 1768- \\
71\end{array}$ & $\begin{array}{l}\text { Fecal impaction in children: report of } 53 \text { cases of rectal seed } \\
\text { bezoars }\end{array}$ & 0 \\
\hline Shaw & 2007 & UK & $\begin{array}{l}\text { J Med Case } \\
\text { Rep }\end{array}$ & $1: 1-4$ & $\begin{array}{l}\text { Large bowel obstruction due to sesame seed bezoar: a case } \\
\text { report }\end{array}$ & 1 \\
\hline Singh & 2007 & Oman & $\begin{array}{l}\text { Australas } \\
\text { Radiol }\end{array}$ & $51: 126-9$ & $\begin{array}{l}\text { Duodenal date seed bezoar: A very unusual cause of partial } \\
\text { gastric outlet obstruction }\end{array}$ & 1 \\
\hline Eitan & 2007 & Israel & J Pediatr Surg & 42:1114-7 & $\begin{array}{l}\text { Fecal impaction in children: report of } 53 \text { cases of rectal seed } \\
\text { bezoars }\end{array}$ & 5 \\
\hline Bedıoul & 2008 & I unis & $\begin{array}{l}\text { Gastroenterol } \\
\text { Clin Biol }\end{array}$ & $\begin{array}{l}32: 596- \\
600\end{array}$ & $\begin{array}{l}\text { A report of } 15 \text { cases of small-bowel obstruction secondary to } \\
\text { phytobezoars: Predisposing factors and diagnostic difficulties }\end{array}$ & \\
\hline
\end{tabular}




\section{Cureus}

\begin{tabular}{|c|c|c|c|c|c|c|}
\hline Kok & 2009 & Turkey & J Emerg Med & $41: 537-8$ & Pumpkin seed bezoar initially suspected as child abuse & 1 \\
\hline Mirza & 2009 & Oman & Trop Doct & $39: 54-5$ & Rectal bezoars due to pumpkin seeds & 1 \\
\hline Schucany & 2009 & USA & $\begin{array}{l}\text { Proc (Bayl } \\
\text { Univ Med } \\
\text { Cent) }\end{array}$ & $22: 164-5$ & Abdominal pain, nausea, and vomiting in a 10 -year-old girl & 1 \\
\hline Kavlakoglu & 2010 & Turkey & $\begin{array}{l}\text { Turkish J } \\
\text { Gastroenterol }\end{array}$ & $22: 442-3$ & $\begin{array}{l}\text { Very rare coincidence: Perforated duodenal ulcer and olive } \\
\text { seed phytobezoar }\end{array}$ & 1 \\
\hline Lane & 2010 & USA & $\begin{array}{l}\text { Pediatr Emerg } \\
\text { Care }\end{array}$ & $26: 662-4$ & $\begin{array}{l}\text { Sunflower rectal bezoar presenting with an acute abdomen } \\
\text { in a 3-year old child }\end{array}$ & 1 \\
\hline Minty & 2010 & Canada & $\begin{array}{l}\text { Can Med } \\
\text { Assoc J }\end{array}$ & 182:91991 & Rectal bezoars in children & 1 \\
\hline Thing & 2010 & Denmark & Ugeskr Laeger & $\begin{array}{l}172: 2905- \\
6\end{array}$ & Rectal bezoar caused by sunflower seeds & 1 \\
\hline Britton & 2011 & $\begin{array}{l}\text { Australia } \\
\text { (Iraqi) }\end{array}$ & $\begin{array}{l}\text { J Paediatr } \\
\text { Child Health }\end{array}$ & $47: 68-9$ & $\begin{array}{l}\text { A case of impacted watermelon seed rectal bezoar in a 12- } \\
\text { year-old girl }\end{array}$ & 1 \\
\hline Chauhan & 2011 & India & $\begin{array}{l}\text { Indian J Radiol } \\
\text { Imaging }\end{array}$ & $21: 21-3$ & $\begin{array}{l}\text { Case report: Colonic bezoar due to Box Myrtle seeds: A very } \\
\text { rare occurrence }\end{array}$ & 1 \\
\hline Slesak & 2011 & Laos & Trop Doct & $41: 85-90$ & $\begin{array}{l}\text { Bowel obstruction from wild bananas: a neglected health } \\
\text { problem in Laos }\end{array}$ & 6 \\
\hline Luporini & 2012 & Brasil & J Coloproctol & 32:308-11 & $\begin{array}{l}\text { Intestinal obstruction caused by phytobezoar composed of } \\
\text { jaboticaba seeds: case report and literature review }\end{array}$ & 1 \\
\hline Manne & 2012 & USA & Clin Med Res & 10:75-7 & $\begin{array}{l}\text { A Crunching colon: Rectal bezoar caused by pumpkin seed } \\
\text { consumption }\end{array}$ & 1 \\
\hline $\begin{array}{l}\text { Martinez- } \\
\text { Pasqual }\end{array}$ & 2012 & Spain & $\begin{array}{l}\text { Rev Esp } \\
\text { Enferm Dig }\end{array}$ & 104:266-7 & $\begin{array}{l}\text { Rectal ulcer secondary to a fecal impaction due to } \\
\text { pomegranate seed bezoar }\end{array}$ & 1 \\
\hline Al-Rashid & 2013 & $\begin{array}{l}\text { Saudi } \\
\text { Arabia }\end{array}$ & BMJ Case Rep & 2013:1-2 & $\begin{array}{l}\text { Beware of what you eat: small bowel obstruction caused by } \\
\text { freekeh bezoars }\end{array}$ & 1 \\
\hline Lim & 2013 & USA & Endoscopy & $45: 65212$ & Unusual cause of constipation: Sunflower seeds bezoar & 1 \\
\hline $\begin{array}{l}\text { El- } \\
\text { Majzoub }\end{array}$ & 2014 & Lebanon & $\begin{array}{l}\text { Ann Saudi } \\
\text { Med }\end{array}$ & $104: 2014$ & Rectal impaction by pomegranate seeds & 1 \\
\hline Kia & 2014 & Iran & $\begin{array}{l}\text { West J Emerg } \\
\text { Med }\end{array}$ & $15: 385-6$ & Intestinal Obstruction Caused by Phytobezoars & 1 \\
\hline Metussin & 2014 & Brunei & $\begin{array}{l}\text { Turkish J } \\
\text { Gastroenterol }\end{array}$ & $25: 270-1$ & Rectal bleeding from seeds impaction & 1 \\
\hline Plataras & 2014 & Greece & BMJ Case Rep & 2014:1-3 & $\begin{array}{l}\text { An unusual cause of small bowel obstruction in children: } \\
\text { lentil soup bezoar }\end{array}$ & 1 \\
\hline Mahmood & 2015 & USA & $\begin{array}{l}\text { ACG Case } \\
\text { Rep J }\end{array}$ & $2: 200-1$ & Rectal Pain and the Colonic Crunch Sign & 1 \\
\hline
\end{tabular}




\section{Cureus}

\begin{tabular}{|c|c|c|c|c|c|c|}
\hline Marchese & 2015 & Italy & $\begin{array}{l}\text { J Biol Regul } \\
\text { Homeost } \\
\text { Agents }\end{array}$ & 29:707-11 & $\begin{array}{l}\text { Rectal impaction due to prickly pear seeds bezoar: a case } \\
\text { report }\end{array}$ & 1 \\
\hline Akrami & 2016 & Iran & $\begin{array}{l}\text { Iran J Public } \\
\text { Health }\end{array}$ & $45: 1080-2$ & $\begin{array}{l}\text { Dietary Habits Affect Quality of Life: Bowel Obstruction } \\
\text { Caused by Phytobezoar }\end{array}$ & 1 \\
\hline Chai & 2016 & Malaysia & Indian J Surg & $78: 326-8$ & $\begin{array}{l}\text { Wild Banana Seed Phytobezoar Rectal Impaction Causing } \\
\text { Intestinal Obstruction }\end{array}$ & 1 \\
\hline Nehme & 2017 & USA & $\begin{array}{l}\text { ACG Case } \\
\text { Rep J }\end{array}$ & 4:e49 & $\begin{array}{l}\text { Pumpkin Seed Bezoar Causing Lower Gastrointestinal } \\
\text { Bleeding }\end{array}$ & 1 \\
\hline Alexandre & 2018 & Portugal & BMJ Case Rep & 2018 & $\begin{array}{l}\text { Giant granadilla's seeds phytobezoar rectal impactation: a } \\
\text { very unusual case of intestinal obstruction }\end{array}$ & 1 \\
\hline Islam & 2018 & $\begin{array}{l}\text { Trinidad } \\
\text { and Tobago }\end{array}$ & $\begin{array}{l}\text { Int J Surg } \\
\text { Case Rep }\end{array}$ & $51: 125-9$ & $\begin{array}{l}\text { Mango seed causing acute large bowel obstruction in } \\
\text { descending colon-world's first reported case }\end{array}$ & 1 \\
\hline Manatakis & 2018 & Greece & Pan Afr Med J & $31: 157$ & $\begin{array}{l}\text { Rectal seed bezoar due to sunflower seed: a case report and } \\
\text { review of the literature }\end{array}$ & 1 \\
\hline
\end{tabular}

\section{TABLE 4: Articles included in the final analysis}

\section{Additional Information \\ Disclosures}

Conflicts of interest: In compliance with the ICMJE uniform disclosure form, all authors declare the following: Payment/services info: All authors have declared that no financial support was received from any organization for the submitted work. Financial relationships: All authors have declared that they have no financial relationships at present or within the previous three years with any organizations that might have an interest in the submitted work. Other relationships: All authors have declared that there are no other relationships or activities that could appear to have influenced the submitted work.

\section{References}

1. Sanders MK: Bezoars: from mystical charms to medical and nutritional management . Pract Gastroenterol. 2004, 28:37-50.

2. Eng K, Kay M: Gastrointestinal bezoars: history and current treatment paradigms. Gastroenterol Hepatol. 2012, 8:776-778.

3. Eitan A, Bickel A, Katz IM: Fecal impaction in adults: report of 30 cases of seed bezoars in the rectum. Dis Colon Rectum. 2006, 49:1768-1771. 10.1007/s10350-006-0713-0

4. Eitan A, Katz IM, Sweed Y, Bickel A: Fecal impaction in children: report of 53 cases of rectal seed bezoars. J Pediatr Surg. 2007, 42:1114-1117. 10.1016/j.jpedsurg.2007.01.048

5. Stroup DF, Berlin JA, Morton SC, et al.: Meta-analysis of observational studies in epidemiology: a proposal for reporting. JAMA. 2000, 283:2008-2012.

10.1001/jama.283.15.2008

6. Do Sameiro Barroso M: The bezoar stone: a princely antidote, the Távora Sequeira Pinto Collection-Oporto. Acta Med Hist Adriat. 2014, 12:77-98.

7. Iwamuro M, Okada H, Matsueda K, Inaba T, Kusumoto C, Imagawa A, Yamamoto K: Review of the diagnosis and management of gastrointestinal bezoars. World J Gastrointest Endosc. 2015, 7:336-345. 10.4253/wige.v7.i4.336 
8. Kement M, Ozlem N, Colak E, et al.: Synergistic effect of multiple predisposing risk factors on the development of bezoars. World J Gastroenterol. 2012, 18:960-964. 10.3748/wjg.v18.i9.960

9. Manatakis D, Sioula M, Passas I, Zerbinis H, Dervenis C: Rectal seed bezoar due to sunflower seed: a case report and review of the literature. Pan Afr Med J. 2018, 31:157. 10.11604/pamj.2018.31.157.12539

10. Padilha De Toledo A, Hurtado Rodrigues F, Rocha Rodrigues M, Tiemi Sato D, Nonose R, Nascimento EF, Martinez CAR: Diospyrobezoar as a cause of small bowel obstruction . Case Rep Gastroenterol. 2012, 6:596-603. 10.1159/000343161

11. Erzurumlu K, Malazgirt Z, Bektas A, et al.: Gastrointestinal bezoars: a retrospective analysis of 34 cases. World J Gastroenterol. 2005, 11:1813-1817. 10.3748/wjg.v11.i12.1813

12. Chen YC, Liu CH, Hsu HH, et al.: Imaging differentiation of phytobezoar and small-bowel faeces: CT characteristics with quantitative analysis in patients with small-bowel obstruction. Eur Radiol. 2015, 25:922-931. 10.1007/s00330-014-3486-1

13. Lee KH, Han HY, Kim HJ, Kim HK, Lee MS: Ultrasonographic differentiation of bezoar from feces in small bowel obstruction. Ultrasonography. 2015, 34:211-216. 10.14366/usg.14070

14. Ladas SD, Kamberoglou D, Karamanolis G, Vlachogiannakos J, Zouboulis-Vafiadis I: Systematic review: Coca-Cola can effectively dissolve gastric phytobezoars as a first-line treatment. Aliment Pharmacol Ther. 2013, 37:169-173. 10.1111/apt.12141

15. Iwamuro M, Kawai Y, Shiraha H, Takaki A, Okada H, Yamamoto K: In vitro analysis of gastric phytobezoar dissolubility by Coca-Cola, Coca-Cola Zero, cellulase, and papain. J Clin Gastroenterol. 2014, 48:190-191. 10.1097/MCG.0b013e3182a39116 